\title{
Utilization of Song and Music Creation in the Digital Era Through Role and Strategy of Collective Management Organizations
}

\author{
Besar \\ Faculty of Humanities, Universitas Bina Nusantara, Jakarta, Indonesia \\ besar@binus.edu
}

\begin{abstract}
Songs and music for human life have economic value, so songwriters and music have the right to benefit from the economic value. The creator or copyright holder often cannot maintain his own rights and submit to the Collective Management Organization whose duty is to collect royalties and then distribute to those who are entitled. The collection of existing royalties is still done manually with a wholesale system so that it often causes problems between song and music users and Collective Management Organization. With the presence of digital technology, it will certainly be easier to determine the amount of royalty that will be collected and distributed. By using digital technology, collecting royalties can be more transparent and provide legal certainty. As the results, it is found that song and music users prefer to use digital technology because it is clear that the obligation must be paid by the user, and transparent to the creator or copyright holder.
\end{abstract}

Keywords: Song And Musik, Writer, Management Organization

\section{INTRODUCTION}

People often assume that copyright is protected with the same time period that is during the life of the creator plus 70 years after the creator dies. In the Copyright Law Number 28 of 2014 (UUHC 2014), it is explained that the validity period of the protection varies, the lifetime of the creator plus 70 years after the creator dies, there are 50 years and some 25 years, this depends on the type of creation that exists. Copyright protection is divided into 2 (two), namely protection of moral rights and protection of economic rights. Protection of the moral rights of the creator is given indefinitely in accordance with Article 57 paragraph (1) UUHC 2014. For economic rights, the protection is given for the life of the creator and continues for 70 years after the author dies, and if the copyright is owned by a legal entity, then the protection period is valid for 50 years from the time the announcement is made.

The type of creation given during the life of the creator plus 70 years after the creator dies, among others, is a song or music with or without text. In mastering its economic rights, the creator or copyright holder cannot independently manage it and then submit it to the Collective Management Institute. Arrangements regarding collection or collection of royalties are still using a manual method which is often referred to as a wholesale method, which often 
causes problems between song and music users and the Collective Management Organization about the amount of royalties to be paid.

In this writing using normative juridical method by using secondary data in the form of literature study, from books, dissertations, theses, researches, scientific writings, and laws. This secondary data is supported by Primary data to strengthen the analysis. The purpose of this paper is to find out how the role and strategy of Collective Management Organization in collecting royalties by using digital technology so that the collection of royalties is felt fair and legal certainty. The role of digital technology in determining the fair collection of royalties and legal certainty will be used continuously.

\section{LITERATURE REVIEW}

Music in the Indonesian Dictionary is "the science or art of arranging tones or sounds in a sequence of combinations and temporal relationships to produce compositions (sounds) that have unity and continuity. The song is a variety of rhythmic sounds. "HanjuandArmillah [1] give a definition:

"Music as an expression of theheart expression that is issued regularly in the form of sound language".In the 2014 UUHC, it limits that: "music or song works as a work that is intact", which according to M. Soeharto[2] the composition of music and songs must be protected.

The concept of protecting songs and music refers to the Preamble of the 1945 Constitution. As a continuation, the state provides legal protection along with legal certainty for all Indonesians, including the creators of music and songs. The conception then raises a theory that works of art, especially music and song, are beneficial to human life and have economic value. The creation of music and songs can lead to four kinds of conceptions, namely the conception of wealth, the conception of rights, the conception of legal protection, the conception of value. As stated by Eddy Damian, who once stated that the concept of the value of a music and song would lead to public appreciation of a copyrighted work.The work of human intellectuals in the field of art and music has been very advanced, supported by digital technology to be increasingly never stop working. By digitizing a work it is easy to use, imitate, or duplicate by other parties with various models. This use, imitation, or duplication by other parties is often not known by the Author or the holder of the Copyright and Related rights.

Music art works are protected by copyright law and copyright related rights which are exclusive rights and to them are given the right to prohibit of apublish or reproduce their creations. If someone intentionally announces or reproduces without permission from the creator is a violation. In the event that the Creator or the Copyright holder and the Related Rights cannot control the use of his work, it is announced or duplicated by another person, it is necessary to have an institution that can help to take care of it. Highly competent institutions are Collective Management Organizations (CMOs) or Collecting Societies [3]. In Indonesia this Collective Management Organization is growing rapidly along with the development of works in the art and music field. Collective Management Organization is an institution in the form of a non-profit legal entity authorized by the creator, copyright holder, and / or related rights to manage its economic rights in the form of collecting and distributing royalties. 


\section{METHOD}

The qualitative case study is used as the method of the research. Researcher using the juridical normative by using secondary data which consist of the study of literature, books, dissertations, scientific writing and the legislation. The secondary data are supported by primary data with interview three user.The purpose of this writing is to know how the role and strategies of collective Management Institutions in collecting royalty by using digital technology so that the royalty collection is reasonably fair and legal certainty

\section{RESULT and DISCUSSION}

Legally the existence and function of the Collective Management Organization is in an effort to protect the rights of the creator and the right holder. the existence of the Collective Management Organization formed under Law No. 28 of 2014 must work in accordance with the laws and regulations, and implement rules and policies on withdrawal of royalties that are felt fair to the creator, copyright holder and related rights, and their presence is useful to protect rights economic works. So that it plays a role in realizing the goals of the country and the desires of the creators, copyright holders and related rights to prosperity can be achieved. However, there are several issues related to the authority of the Collective Management Organization in determining the amount of royalties that is not yet clear [4]. This can cause problems later for copyright users for commercial purposes. This institution is to help musicians get their rights which are used commercially by karaoke places, cafes, restaurants or other business fields. In Indonesia there are several Collective Management Organization such as: KCI, WAMI, RAI, Asirindo and so on. The role of these institutions must be under the umbrella of the National Collective Management Organization[5].

The existence of this Collective Management Organization is considered very important, because with the existence of the Collective Management Institute, composers will continue to focus on efforts to produce songwriting works, as well as the publisher (record label) they will focus on music marketing activities. This Collective Management Organization carries out its function to manage Music Copyright especially for royalties on the Right to Perform (Rights), to be licensed to various parties conducting Performing Rights activities, such as: Live Concert, Hotels, Restaurants and Cafes, Shopping Centers, Cinema, Karaoke, RBT, Ringtone and Website, Transportation and Amusement Park, and channel the royalties paid to the creator (composer) and the relevant holder (publisher).

In the implementation of royalty billing, the Collective Management Organization still uses manual calculations by counting the number of rooms multiplied by the daily rate per year of the karaoke service provider. The institution sets a tariff of IDR 12,000 multiplied by the space owned per day of operation [6]. While for karaoke exclusive IDR 50,000 per hour,[7] for family karaoke IDR. 20,000 and for without room IDR 15,000, less basic and not in accordance with the conditions in the field, the karaoke businessman proposes to use technology [8]. This manual tariff determination still often causes conflict between song and music users and the Collective Management Organization. The mechanism for collecting royalties from songs and music from karaoke entrepreneurs in bulk as above, regardless of the rate per room per year, is not the right system. Then many cases such as the Inul Vista karaoke house, Alexis,[9] were included in the cases in Bogor, and others who were concerned about the amount of royalties that had to be paid by the user.

Digital technology, which is supported by multimedia on the one hand, results in the difficulty of protecting copyrighted works. Because with digital technology can do any 
violations. Technology provides a very permissive means by providing facilities for copying, plagiarism, mutilation and so on to the works of others. By enabling and operating infrared, data cable, blue tooth or activating Wi Fi LAN, you can exchange song and music files.

The coping strategy for violations of songs and music, the role of the Collective Management Organization is very central. Collective Management Organization uses digital technology to limit and regulate the use of songs and music to determine the amount of royalty that can be imposed on users.

Collective Management Organization using digital technology will easily solve existing problems, for example the amount of royalties at the karaoke house that must be paid. This digital technology can be taken as an example is the use of songs and music for Ring Back Tone. By using Digital technology, it can be used to calculate how many songs are down loaded, what songs are liked and ultimately can directly determine the amount of royalty for the copyright holder.

By using digital technology, at each karaoke house can be known

1. How many types of songs are used

2. How many songs are played or used by users

3. Songs that are used and songs that are never used by users

The royalty withdrawal mechanism should the government implement a technology-based royalty withdrawal system using digital technology that is easy and inexpensive as it has been implemented in America, Malaysia and Singapore.[10] Therefore, royalty fees from karaoke companies are based on how many songs and songs what is played in the karaoke room, every day for a year. Distribution of royalties by using digital technology to the rightful is more accurate, and karaoke companies will pay royalties in accordance with the formulation that provides certainty. With a system of wholesale royalties per room per year as it is now running, royalties that will be distributed to royalty holders have no clarity. By applying this technology all calculations are detailed and transparent,[11] clearly what songs and how many times they are played. With royalty rates per song, for example IDR 200 per play, then the calculation of the withdrawal and the royalty distribution is also clear, and none of the parties are harmed.

In tackling the issue of song and music copyright, collaboration needs to be carried out between the Collective Management Institute, DJKI and the Ministry of Communication and Information.

The concept of economic development in Indonesia is adopted from the concept of development in European and American countries. The legal system that is intended to support economic development is felt that the law in Indonesia is patterned on the economic development framework as seen in the legislation in the field of Intellectual Property. Intellectual Property legislation is "..body of law concerned with protecting both creative efforts and economic investment in creative effort.

Intellectual Property Law is a political product which is a tug of war or at least there are mutual influences affecting the interests between Developing Countries and Developing Countries. The concept of protecting Intellectual Property at the international level in the TRIPS Agreement as well as in other international conventions, as well as the application of legislation on Intellectual Property, shows that there are interests of interest in society, in connection with the development of multimedia engineering.

The development of science and technology that develops very rapidly brings consequences to changes in human behavior physically and psychologically, materially and morally, on the moral side, the way of law and the value of justice. 
Moral influence and also influenced by multimedia science and technology. The development of multimedia science and technology as a result of human culture on the one hand can help humans become easier in their lives and as a means of humanization but on the other hand lead to erosion of moral values.

In bridging good and bad problems as above, it is necessary to have rules that are binding on human beings so that humans always follow the existing rules, so that humans are said to have good morals and can be said to be moral beings if they obey the rules of morality.

Law is a government tool to regulate society fairly. The purpose of law is to achieve justice, then the law must be in accordance with the principles of justice, and the law is considered a law if it meets the principles of justice. The law was created to make things feel fair and orderly so that prosperity will be realized in accordance with the objectives of the Indonesian State.

The legal purpose according to Bentham is that in addition to providing certainty and justice it also provides as much benefit and happiness to the community. Bentham mentioned that "The aim of law is The Greatest Happiness for the greatest number". The purpose of the law is "the greatest happiness of the greatest number" (happiness as much as possible for as many people as possible). The purpose of the law can be seen how much the impact is on human welfare. The 2014 UUHC, when viewed from Bentham's utilitarianism theory, has provided a picture of law that can benefit many people.

\section{CONCLUSION}

The work of songs and music that have economic value that is protected by copyright law, must be maintained so that no one else uses the creation to the detriment of others. The implementation of the economic value of the creator and copyright holder cannot be done by using a gray mechanism. In order for the rights of the creators to be in accordance with the efforts and in accordance with the true law, the method of implementing economic rights in the form of royalties cannot be applied using a wholesale or manual method and must be replaced with a mechanism that uses digital technology to be more accurate and transparent. Collective Management organization in determining the amount of royalty tariff must use real time for the use of the song.

\section{REFERENCE}

[1] Hanju and Armillah, Pengetahuan Seni Musik. Jakarta: Mutiara, 1981.

[2] M. Soeharto, Belajar Membuat Lagu. Jakarta: Gramedia, 1986.

[3] C. Waelde, A. Brown, S. Kheria, and J. Cornwell, Contemporary Intellectual Property (DRAFT). Oxford University Press, 2016.

[4] CNN Indonesia, "Mengurai Ruwetnya Masalah Royalti Karya Cipta," CNN Indonesia, 2015. [Online]. Available: https://www.cnnindonesia.com/hiburan/20150309193523227-37835/mengurai-ruwetnya-masalah-royalti-karya-cipta.

[5] Presiden Republik Indonesia, Undang-Undang Republik Indonesia Nomor 28 Tahun 2014 pasal 89 ayat (1). 2014.

[6] R. S. Pradana, "Royalti Musik LMKN Tetapkan Tarif Untuk Sejumlah Sektor," Bisnis.com, 2015.2 [Online]. Available: http://lifestyle.bisnis.com/read/20151220/225/503606/royalti-musik-lmkn-tetapkantarif-untuk-sejumlah-sektor.

[7] M. Amelia, "Kata Asosiasi Pengusaha Hiburan Soal Kasus Royalti di Alexis," Detik, 
2017. [Online]. Available: https://news.detik.com/berita/d-3437646/kata-asosiasipengusaha-hiburan-soal-kasus-royalti-lagu-di-alexis.

[8] I. R. Cahyadi, "Penghitungan Royalti Lagu dengan Teknologi Dinilai Lebih Adil," Berita Satu, 2017. [Online]. Available: https://www.beritasatu.com/hiburan/421130perhitungan-royalti-lagu-dengan-teknologi-dinilai-lebih-adil.html.

[9] M. Amelia, "Polisi: Pengusaha Karaoke yang Tidak Bayar Royalti Lagu Bisa Dipidana," Detik, 2016. [Online]. Available: https://news.detik.com/berita/d3315219/polisi-pengusaha-karaoke-yang-tidak-bayar-royalti-lagu-bisa-dipidana.

[10] JPNN, "Musisi Kritik Sistem Penarikan Royalti dari Karaoke," JPNN, 2017. [Online]. Available: https://www.jpnn.com/news/musisi-kritik-sistem-penarikan-royalti-darikaraoke.

[11] Dahwilani D M, "Pelaku Industri Kreatif Usul," Sindo News, 2017. [Online]. Available: https://ekbis.sindonews.com/read/1190336/34/pelaku-industri-kreatifusulkan-penarikan-royalti-berbasis-teknologi-1490091915. 